\title{
Development of CAT-based student worksheets to improve basic students 'mathematical understanding abilities
}

\author{
Patri Janson Silaban, Universitas Katolik Santo Thomas, Indonesia, patri.jason.silaban@gmail.com, ORCID: \\ 0000-0002-5619-3775 \\ Dewi Anzelina, Universitas Katolik Santo Thomas, Indonesia, dewi_anzelina@ust.ac.id, ORCID:0000-0002- \\ 2405-1967 \\ Regina Sipayung, Universitas Katolik Santo Thomas, Indonesia, sipayungregina1@gmail.com, ORCID: \\ 0000-0002-6633-7429
}

Rumiris Lumban Gaol, Universitas Katolik Santo Thomas, Indonesia, rumiris20lumbangaol@gmail.com, ORCID: 0000-0002-3643-3153

Dyan Wulan Sari HS, Universitas Katolik Santo Thomas, Indonesia, dyanwulans@yahoo.com, ORCID:00000001-6766-7641

Juliana, Universitas Katolik Santo Thomas, Indonesia, anna.jait@gmail.com, ORCID:0000-0002-7533-4027

\begin{abstract}
Basically, the ability of Mathematical Comprehension is an ability that can be trained for every student. Students Worksheet is a learning aid in the learning process. One of them is CAT (Computer Assisted Test)-based Students Worksheet. CAT is a learning medium that is designed to be used to develop interactive Students Worksheet related to integer arithmetic operations. This research method is the method of Research and Development. The subject of this research is class VI Methodist-12 Private SD Medan Academic Year 2019/2020. The variables to be measured are proof of important analytical and experimental functions and / or characteristics which includes the accuracy of CAT-based Students Worksheet design, comprehension ability. student mathematics and the effectiveness and efficiency of use.
\end{abstract}

Keywords: Students worksheet, cat, mathematical comprehension ability.

Received: 05.11.2020 Accepted: 04.12.2020 $\quad$ Published: 02.01.2021

\section{INTRODUCTION}

The learning process is a complex process that happens to every person throughout his life, the learning process due to the interaction between man and his environment. Therefore, learning can happen anywhere and anytime. One sign that a person has to learn is by a change in the level of knowledge, skills and attitude. In this case, the mathematics also need to be studied because it can increase the level of knowledge, skills, attitudes toward student learning.

Quality learning is very dependent on student motivation and teacher creativity. Good learning design, supported by clever facilities, coupled with teacher creativity will make it easier for students to achieve learning targets. In reality in the field the learning process carried out at this time has not met the expectations of teachers as a development of learning strategies in the classroom. Students experience difficulties in learning mathematics, especially in solving problems related to students' mathematical understanding abilities. Student Worksheets can be used as self-teaching, educating students to be independent, confident, disciplined, responsible and able to make decisions. Students Worksheet in teaching and learning activities can be used at the concept planting stage (conveying new concepts) or at the concept planting stage (the advanced stage of concept planting). The use of Students Worksheet at the conceptual understanding stage means that Students Worksheet is used to study a topic that has been studied in the previous stage, namely concept planting. Students Worksheet objectives; Providing concrete experiences for students, helping variation in learning, arousing student interest, increasing retention of teaching and learning, utilizing time effectively and efficiently.

The use of media in learning mathematics is necessary because the media has the advantage of technical ability, was able to present the advantages of a real event, presents the concept of integrated or complete and correct and be a conduit or intermediary in conveying the message to learners. Teachers are also expected to use the media that according to the situation of students in order to improve student learning outcomes in all subjects one of them by using LKPD-based CAT (Computer assited Test) which is managed from the software macromedia flash. Macromedia Flash is a way of learning that is effective, efficient, and fun. So as to provide real experiences that can stimulate students can improve student learning hasi. To address the problems that arise in the learning process, development CAT-based Students Worksheet to improve students' mathematical understanding. 


\section{Theoretical Underpinnings}

\section{Mathematics Learning}

According to James (in Ruseffendi 1992: 27) argues that mathematics is the science of forms, arrangements, quantities and concepts that are interconnected with each other in large numbers divided into three fields, namely algebra, analysis, and geometry. According to Reys (in Ruseffendi 1992: 28) argues that mathematics is an analysis of the patterns and relationships of a path or pattern of thinking in an art, a language, and a tool. According to Karim, et al. (1997) states the purpose of providing mathematics at the basic education level is essentially can be divided into two parts, namely general goals and specific goals. According to Ruseffendi (1992) argues that the benefits of Mathematics for mankind are 1) by learning Mathematics, humans can solve problems that exist in society, namely in daily communication such as being able to count, 2) mathematics is taught in schools because mathematics can help other fields of study, 3 ) by studying spatial geometry, students can improve their ability to understand space so that they think logically and accurately in the third dimension, 4) it can be used as a forecasting tool such as weather forecasting, population growth, learning success, etc. 5) as a support the use of sophisticated tools such as calculators and computers, 6) for the maintenance of mathematics itself for the sake of cultural improvement.

\section{Students' Mathematical Comprehension Ability}

According to Sumarto (in Susanto, 2013: 210), at least a person must know five important aspects, namely: a) the object itself, b) its relation to other similar objects, c) its relations with other objects that are not the same, d) relations dual with other similar objects, and e) relations with objects in other theories. In terms of type, according to Russefendi (in Susanto 2013: 210), he argues that there are three kinds of mathematical understanding, namely: translation, interpretation, and extrapolation. Bloom clarifies understanding into the second cognitive level which describes an understanding, so that someone knows how to communicate and puts forward his ideas to communicate. In understanding not only understanding an information but also the objectivity, attitude, and meaning contained in something information. In other words, a person can change the information he has in his mind into other, more meaningful forms.

Meanwhile, according to Skem (in Susanto 2013: 211), understanding can be divided into two types, namely instrumental and relational understanding. According to Anderson \& Krathwohl (2001) divides into seven categories of cognitive understanding processes including: interpreting, exemplifying, classifying, summarizing, inferring, comparing, and explaining (explaining).

\section{CAT Based Student Worksheet}

Student Worksheets are supporting learning resources that can improve students' understanding of the material they must master (Senam, 2008). Students Worksheet is a tool to convey messages to students which are used by teachers in the learning process. Through this Students Worksheet, it will make it easier for teachers to deliver learning materials and streamline their time, and will lead to interactions between teachers and students in the learning process. According to Sriyono (1992), Students Worksheet is a form of program that is based on tasks that must be completed and functions as a tool to transfer knowledge and skills so as to accelerate the growth of student interest in participating in the learning process. The use of Students Worksheet media is expected to provide benefits in the learning process, this is as stated by Arsyad (2005), including: 1) Clarifying the presentation of messages and information so that the learning process runs smoothly and can improve learning outcomes, 2) Increase student motivation by directing students' attention, so as to allow students to learn on their own according to their abilities and interests, 3) The use of media can overcome the limitations of senses, space, and time, 4) Students will get the same experience about an event and allow it to happen- direct interaction with the surrounding environment. Not only that, through worksheets, students are expected to be motivated in learning chemical concepts, especially in the material of buffer solutions.

In the learning process, Students Worksheet is used as a learning tool to guide students in exploring material from a subject matter or subject matter that has been or is being carried out. Students Worksheet must express opinions and be able to draw conclusions. The Computer Assisted Test is defined as an examination method using computer aids that are used to obtain a minimum standard of basic competence and personnel competency standards (Sutrisno, 2014). The process stages in CAT system design begin with research and data collection, then planning, making prototypes, implementing tests. tried it, and it followed improvement and development. The CAT system prototype has the following characteristics: (1) The application uses a website-based windows or open source platform; (2) There is a narrative containing instructions that are presented on a computer monitor screen; (3) The application is 
accompanied by video mouse movements to make it easier for users to operate, and (4) Equipped with tutorials and text containing instructions on the computer monitor screen so that all test takers are easy to operate. According to Sutrisno (2014), CAT as one of the methods used in the implementation of the test has the following basic principles; (1) The CAT system is designed to be as easy as possible, so that test takers can operate it; (2) How to operate it is very easy, even for beginners because it only uses the mouse to do the test questions and choose answers. The committee is obliged to provide directions and display video instructions on how to operate the CAT system to provide instructions for using the CAT system; (3) The questions in the CAT application vary but with an equal level of difficulty. Participants get different questions, and the questions are randomized automatically and then distributed to each participant's computer; and (4) Direct test results are checked by the application automatically. Participants' scores can be monitored simultaneously through the monitoring room outside the test venue. Meanwhile, participants can find out the value obtained immediately after completing the exam through the monitor screen of each computer.

\section{METHODS}

\section{Types of Research}

This research is included in research and development (Research and Development). As Sugiyono (2010) argues that $R \& D$ is a research method used to produce certain products and test the effectiveness of these products. This method is used with the aim of developing CAT-based student worksheets for grade VI SD Methodist-12 Medan on integer arithmetic operations. This research was conducted at 12 Methodist Private SD Medan, located on Jl.Panca No. 28 Marendal Harjoasi II Village, Medan Amplas District.

\section{Research Subjects and Objects}

The subjects of this study were class VI Methodist 12 Private SD Medan for the 2019/2020 academic year. The object of this research is the CAT-based student worksheet Research Variable.

The variables in this study are as follows:

1. Validity of the accuracy of mathematics learning materials in class VI related to integer arithmetic operations.

2. Validity of instructional design accuracy

3. Validity of the accuracy of CAT-based student worksheets.

4. Students' mathematical understanding ability as measured by essay test related to integer arithmetic operations.

5. Student responses to CAT-based student worksheets related to integer arithmetic operations.

6. Teacher responses to CAT-based student worksheets related to integer arithmetic operations.

\section{Development Style}

The development of mathematics learning media is a process to determine or create certain conditions that cause students to interact so that behavior changes. One model that is suitable for developing learning media is the 4-D learning model. The 4-D device development model consists of 4 development stages, namely Define, Design, Develop and Disseminate or adapt it to a 4-D model, namely defining, designing, developing and distributing. As Reynolds in Rochmad (2012: 67) explains the stages of developing the Four-D model, namely:

\section{Define}

The purpose of this defining stage is to define and define what is required in instructional. There are 5 things that are taken at this stage, namely:

1. Front-end analysis. Investigate the basic problems faced by teachers regarding teacher performance levels. It is during this investigation that better and more efficient alternative solutions can be considered

2. Learner analysis. Identify the character of the students that will be faced. The characters intended are the competence and background of the student's learning experience, general behavior towards learning topics, media selection, format and language to be used.

3. Task analysis . Identify the main skills needed and break them down into more specific skills which are necessary and sufficient.

4. Concept analysis. Identify the main concepts to be taught, organize the concepts into a hierarchy and detail the nature or characteristics of each concept. This analysis helps identify a set of 
thoughts about examples that could be brought up in development.

5. Speccifying instructional objectives. Converting the results of task analysis and concept analysis into goals in the form of expected behavior. This set of objectives is the basis for the preparation of tests, design and subsequently these objectives are integrated into the subject matter.

\section{Design}

The purpose of this stage is to design the beginning of the learning material. This stage can be started if the objectives of the subject matter have been set at the previous stage. There are four steps at this stage, namely:

1. Constructing criterion test. This step is a bridge that connects stages I and II. The criteria developed convert the objectives into a framework of learning material.

2. Media selection. Selection of appropriate media to present the content of learning. This process includes sources, deployment plans and characteristics of the media.

3. Format selection. This step is related to the previous media selection. The learning format refers to media communication, teaching strategies and usage techniques. The choice of this format depends on the visual, audiovisual, non-verbal format and so on.

4. Initial design. Presenting the basics of learning through appropriate media and in the appropriate order. This step also includes arranging various learning activities such as reading books, interviewing specific students and applying different skills with attention to each student.

\section{Develop}

The purpose of this development step is to modify the learning material in the initial draft. The results from the design stage should be considered preliminary so that an effective final version is required. There are two steps in this stage, namely:

1. Expert appraisal. Is a technique for obtaining suggestions for improving material. A number of experts were asked to evaluate the material from a learning and engineering point of view. It is based on expert feedback that the initial draft has been modified.

2. Developmental testing. Try out the material with students to determine the sections that need revision. Based on student responses and student comments, the material can be modified. The cycle of testing and revising is carried out in order to obtain material that is consistent and effective.

\section{Disseminate}

The final draft of the learning material is obtained if the development test phase shows consistent results from the expert giving positive comments. There are three steps, namely:

1. Validating testing. In this step, the material is used in artificial conditions which demonstrate who is learning, what is being learned, under what conditions and how much time is used. In this step the material is also brought to a professional examination in order to obtain an objective opinion on its adequacy and relevance.

2. Packaging. Producers and distributors are selected and work cooperatively together to package materials in acceptable forms.

3. Diffusion and adopting. A special effort is needed to disseminate material widely to teachers and students in an acceptable form.

\section{Data Collection Instruments}

The data collection instruments used were as follows:

\section{Assessment Questionnaire Sheet}

The questionnaire sheet in this study is a sheet of assessment or suggestions for products or learning media for improving the media produced in the implementation of research. The questionnaire sheet consists of:

1. Questionnaire sheets for material experts, namely an assessment of the quality of learning material and the development of aspects of the learning delivery system

2. Questionnaire sheets for instructional design experts in learning, namely an assessment of the quality of instructional and technical designs of instructional media

3. Questionnaire sheets for media experts, namely the quality of software engineering developed, especially learning media

4. Questionnaire sheets for students are responses to the use and benefits of the learning media being 
developed

5. The teacher's perception questionnaire sheet is the teacher's response to the use and benefits of the learning media developed

\section{Testing of Test Instruments}

\section{Test Validity}

To measure the test used Pearson Product Moment correlation (Arikunto, 2009: 72) by correlating the scores obtained by students on an item with the total score. The formula used is:

$\mathrm{Rxy}=\frac{N \Sigma x y-(\Sigma x)(\Sigma y)}{\sqrt{\left(N \Sigma X^{2}-\Sigma X\right)^{2}\left(N \Sigma Y^{2}-\Sigma Y\right)^{2}}}$

(Arikunto, 2014: 231)

Information

Rxy $=\mathrm{x}$ and $\mathrm{y}$ correlation coefficient

$\mathrm{N}=$ Number of respondents / number of students taking the test

$\mathrm{X}=$ The total score obtained by students for each item of question

$\mathrm{Y}=$ Total number of scores correct

To determine the significance of the correlation obtained, tested with the formula t:

$t=r_{x y} \sqrt{\frac{N-2}{1-\left(r_{x y}\right)^{2}}}$

With;

$\mathrm{t}=$ difference power $\mathrm{t}$ test

$\mathrm{N} \quad=$ number of subjects

$\boldsymbol{r}_{\boldsymbol{x}}=$ correlation coefficient between item scores and total scores

Determine the validity of an item. The criteria that must be met in order for an item to be said to be valid are if $\mathrm{t}$ count $>\mathrm{t}$ table with $\mathrm{t}$ table $=\boldsymbol{=} \boldsymbol{t}_{(\mathbf{1 - \alpha})(\boldsymbol{d k})}(\mathrm{dk})$ ) for $\mathrm{dk}=\mathrm{N}-2$ and (significance level) is chosen $5 \%$.

Table 1. To interpret the reliability coefficient of an evaluation tool (Arikunto, 1999) provides the following criteria:

\begin{tabular}{|l|l|}
\hline $0,80-1,00$ & Very high \\
\hline $0,60-0,79$ & High \\
\hline $0,40-0,59$ & Sufficient \\
\hline $0,20-0,39$ & Low \\
\hline $0,00-0,19$ & Very low \\
\hline
\end{tabular}

\section{Reliability Test}

The reliability of the test instrument is calculated to determine the determination of the test results. To calculate the reliability of this test item, a formula is used in accordance with the form of the essay test, namely the alpha formula as follows:

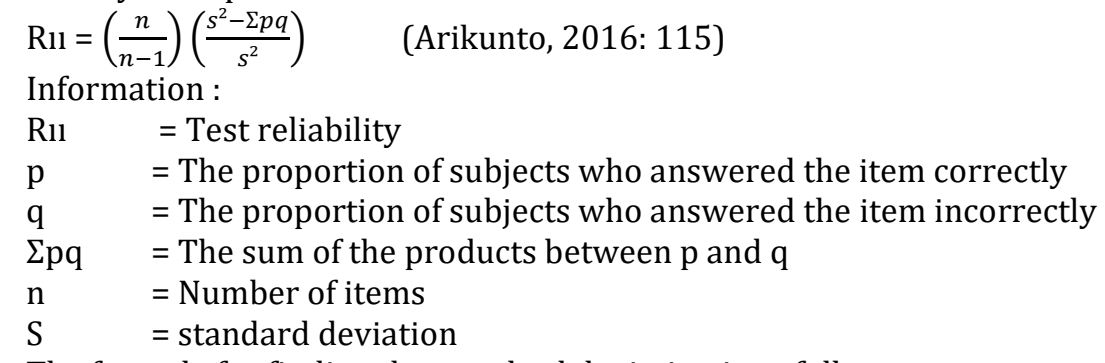

The formula for finding the standard deviation is as follows:

$\mathrm{SD}=\sqrt{\frac{\Sigma f x^{2}}{N}}$

Information :

$\mathrm{SD} \quad=$ Standard Deviation

$\Sigma \mathrm{fx}^{2} \quad=$ the number of times the frequency of each interval by the frequency squared

$\mathrm{N} \quad=$ number of samples

The interpretation of the value of r11 refers to Jihad and Haris (2012: 180) as presented in table 2. 
Table 2. Qualification Correlation Coefficient

\begin{tabular}{|l|l|}
\hline Correlation Coefficient & Qualification \\
\hline $0,80<r_{x y} \leq 1,00$ & Degree very high \\
\hline $0,60<r_{x y} \leq 0,80$ & Degree high \\
\hline $0,40<r_{x y} \leq 0,60$ & Degree is sufficient \\
\hline $0,20<r_{x y} \leq 0,40$ & Degree low \\
\hline$r_{x y} \leq 0,40$ & Degree very low \\
\hline
\end{tabular}

\section{Data Analysis Techniques}

The data analysis techniques in this study are as follows:

1. Media Validation

a. Expert Validation

Data analysis in this study used quantitative descriptive analysis. Furthermore, from the data obtained, the results are averaged and used to assess the quality of the product being developed. The product criteria will be converted into a value with a scale of five using a Likert Scale which is analyzed descriptively (average score and percentage), which is to calculate the percentage of indicators from each category on the Lectora Inspire media that has been developed using the formula:

Empirical score $=\frac{\text { Total score obtained }}{\text { Total ideal score of all items }} \boldsymbol{x} 100 \%$

Furthermore, the percentage of validity criteria can be seen in Table 3.

Table 3. Percentage of Indicator Conformity Criteria

\begin{tabular}{|l|l|l|}
\hline Criteria & Interval Percentage & Information \\
\hline Very good & $85 \% \leq \mathrm{X} \leq 100 \%$ & No need for revision \\
\hline Good & $75 \% \leq \mathrm{X} \leq 84 \%$ & No need for revision \\
\hline Moderate & $65 \% \leq \mathrm{X} \leq 74 \%$ & Revised \\
\hline Less & $55 \% \leq \mathrm{X} \leq 64 \%$ & Revised \\
\hline Very poor & $0 \% \leq \mathrm{X} \leq 54 \%$ & Revised \\
\hline
\end{tabular}

Whereas in calculating the feasibility level of macromedia flash media as a learning medium, the assessment is as follows:

Table 4. Percentage of Eligibility Level Criteria

\begin{tabular}{|l|l|}
\hline Eligibility & Score \\
\hline Not worth & $<65 \%$ \\
\hline Less feasible & $65 \%-74 \%$ \\
\hline Eligible & $75 \%-84 \%$ \\
\hline Very feasible & $85 \%-100 \%$ \\
\hline
\end{tabular}

\section{Teacher and Student Responses}

Data regarding teacher and student responses to macromedia flash media as a developed learning medium, were given a questionnaire after learning fractions material was finished. The criteria for conformity assessment with indicators of teacher and student responses to macromedia flash media as learning media can be seen in table 5 below:

Table 5. Percentage of Teacher and Student Response Criteria according to Indicators

\begin{tabular}{|l|l|l|}
\hline Criteria & Interval Percentage & Information \\
\hline Very good & $85 \% \leq \mathrm{X} \leq 100 \%$ & No need for revision \\
\hline Good & $75 \% \leq \mathrm{X} \leq 84 \%$ & No need for revision \\
\hline Moderate & $65 \% \leq \mathrm{X} \leq 74 \%$ & Revised \\
\hline Less & $55 \% \leq \mathrm{X} \leq 64 \%$ & Revised \\
\hline Very poor & $0 \% \leq \mathrm{X} \leq 54 \%$ & Revised \\
\hline
\end{tabular}

\section{Lesson Plan validation}

Lesson Plan validation is carried out based on 3 aspects of the assessment, namely format, language and content. The average percentage score for RPP validation can be seen in table 6 below: 
Table 6. Percentage of Average Score of Lesson Plan Validation

\begin{tabular}{|l|l|l|}
\hline Criteria & Interval Percentage & Information \\
\hline Very good & $85 \% \leq \mathrm{X} \leq 100 \%$ & No need for revision \\
\hline Good & $75 \% \leq \mathrm{X} \leq 84 \%$ & No need for revision \\
\hline Moderate & $65 \% \leq \mathrm{X} \leq 74 \%$ & Revised \\
\hline Less & $55 \% \leq \mathrm{X} \leq 64 \%$ & Revised \\
\hline Very poor & $0 \% \leq \mathrm{X} \leq 54 \%$ & Revised \\
\hline
\end{tabular}

2. Improvement of Students' Mathematical Comprehension Ability

To determine the increase in students' mathematical understanding abilities, a pre-test and a posttest were carried out. The results of both tests are calculated using the N-gain:

$(g)=\frac{(\text { gain })}{(\text { gain })_{\text {Max }}}=\frac{(\text { postest })-(\text { pretest })}{100-(\text { pretest })}$

Table 7. The criteria for improvement are defined as follows:

\begin{tabular}{|l|l|}
\hline $\mathrm{g}<0,3$ & Category Low \\
\hline $0,3 \leq \mathrm{g} \leq 0,7$ & Category Medium \\
\hline $\mathrm{g} \geq 0,7$ & Category High \\
\hline
\end{tabular}

\section{RESULTS}

Expert assessment of the material in this study carried out by one person validator in the field of mathematics education. As for the aspect in which the feasibility assessment of content, presentation, linguistic and kegrafikan. That ratings matter expert in the study carried out by one person validator in the field of mathematics education. As for the aspect in which the feasibility assessment of content, presentation, linguistic and kegrafikan. The results of the expert assessment of the material that as pect of Contents Eligibility for $98.75 \%$, amounting to $86.67 \%$ Presentation, Linguistic amounted to $86.67 \%$ and Kegrafikan by $80 \%$. The average value of the four aspects of $88.02 \%$ in the category of Very Good.

The Instructional Design Expert's Assessment of CAT-based student worksheets shows that the media expert's assessment is that the Feasibility aspect of the media is $93.33 \%$, the Feasibility of the content is $96.25 \%$, the Presentation is $93.33 \%$, and the Graphics is $80.00 \%$. The four aspects are in the Very Good category. The average value of these two aspects is $90.73 \%$ in the Very Good category.

The Media Expert's assessment of the CAT-based student worksheets that the Feasibility aspect of the media is $90.00 \%$ and the Feasibility of the content is $97.50 \%$, Presentation is $97.50 \%$. These three aspects are in the category of Very Good. The average value of these two aspects of $95.00 \%$ in the category of Very Good.

Student Response Assessment Test Individual learners to worksheet based paint that student responses in this study carried out by a single person six graders. As for the aspects of student responses to the individual test that is the content, purpose, eligibility, technical quality and appeal. The results of the test data analysis of individual student responses that aspect of Contents by $100.00 \%, 100.00 \%$ for the purpose, eligibility for $93.33 \%, 95.00 \%$ for engineering quality and attractiveness of $930.00 \%$. The fifth aspect in the category of Very Good. The average value of the five aspects of $92.00 \%$ in the category of Very Good.

Student Response Assessment worksheet to learners based CAT Trial Small Group that the response of students in the study performed by six people six graders. As for the aspects of student responses to the individual test that is the content, purpose, eligibility, technical quality and appeal. The results of the test data analysis of individual student responses that aspect of learning content by $93.33 \%$, amounting to $93.33 \%$ of interest, feasibility by $91.11 \%$, amounting to $90.00 \%$ engineering quality and attractiveness of $92.50 \%$. The fifth aspect in the category of Very Good. The average value of the five aspects of $92.00 \%$ in the category of Very Good.

Student Response Assessment worksheet to learners based on Field Trial CAT that the response of students in the study carried out by 34 people six graders. As for the aspects of student responses to the individual test that is the content, purpose, eligibility, technical quality and appeal. Results of the analysis of student response data field test that aspect of Contents by $98.08 \%$, amounting to $96.08 \%$ of interest, feasibility by $93.92 \%$, amounting to $92.65 \%$ engineering quality and attractiveness of $95.15 \%$. The fifth aspect in the category of Very Good. The average value of the five aspects of $94.77 \%$ in the category of Very Good.

Response Rate worksheets teachers to learners based CAT that the responses of teachers in the study carried out by a person that sixth grade teacher and subject teachers in elementary mathematics 
Methodist 12 Terrain. As for the aspects of teacher feedback, namely the content, purpose, eligibility, technical quality and appeal. The results of the test data analysis of individual student responses that aspect of Contents of $93.33 \%$, a goal of $100.00 \%$, the feasibility of $86.67 \%$, amounting to $90.00 \%$ quality and attractiveness of $90.00 \%$. The fifth aspect in the category of Very Good. The average value of the five aspects of $92.00 \%$ in the category of Very Good.

Data on the improvement of students' mathematical comprehension abilities in terms of field trials obtained an average pretest score of 53.60 while the post-test average score was 89.0. The average increase is 35.4. The minimum gain value is 0.5 while the maximum gain value is 0.7 . The average value of the data gain on students' mathematical understanding ability on the field trial was 0.8 (high category). Data on the improvement of students' mathematical comprehension abilities in terms of distribution obtained the pretest average score of 54.12 while the post-test average score was 88.68 . The average increase was 34.56 . The minimum gain value is 0.5 while the maximum gain value is 0.8 . The average value of the data gain on students' mathematical understanding ability on the field trial was 0.8 (high category). Thus it can be stated that using CAT-based Students Worksheet in learning related to integer material can improve students' mathematical understanding abilities. It was found that the correlation between the CAT-based Students Worksheet and the students' mathematical understanding ability was 0.965. This shows that there is a strong relationship between CAT-based Students Worksheet and students' mathematical understanding abilities. While the direction of the relationship is positive because the value of $r$ is positive, meaning that the better the CAT-based Students Worksheet is developed, the more it will improve the students' mathematical understanding. Because of the significance value 0.00 $<0.05$ ), Ho is rejected, meaning that there is a significant relationship between CAT-based Students Worksheet and students' mathematical understanding abilities. Because the correlation coefficient is positive, it means that CAT-based LKPD has a positive and significant relationship with students' mathematical understanding abilities.

To find out the effect of CAT-based Students Worksheet on students' mathematical understanding abilities, the $\mathrm{R}$ value which is a symbol of the correlation coefficient value is 0.965 . This value can be interpreted that the relationship between CAT-based Students Worksheet and students' mathematical understanding ability is strong. Through this table, it is also obtained that the value of R Square or the coefficient of determination obtained is $93.1 \%$ which means that the CAT-based Students Worksheet variable has a contribution effect of $93.1 \%$ on students' mathematical understanding abilities and the other $6.9 \%$ is influenced by factors- other factors outside the CAT-based Students Worksheet variable.

\section{DISCUSSION AND CONCLUSION}

The discussion based on research results that can be taken into consideration are: (1) CAT-based Student Worksheets need to be applied by teachers so that learning is interesting and innovative, (2) CAT-based Student Worksheets need to be developed on other subjects in order to develop various activities and student creativity in learning, (3) There needs to be further research by applying it to different subjects

The conclusions in this study are as follows: (1) CAT-based Student Worksheets are feasible to be developed and good to be applied in learning, (2) CAT-based Student Worksheets have a positive and significant relationship with students' mathematical understanding abilities, (3) CAT-based Student Worksheets have a positive effect on students' mathematical understanding abilities.

\section{REFERENCES}

Anderson, L. W., \& Krathwohl, D. R. (Eds.) (2001). A taxonomy for learning, teaching, and assessing:A revision of Bloom's taxonomy of educational Objectives. New York: Longman.

Aprisya Krispriana, dkk (2016) Sistem Informasi Computer Assisted Test (CAT)Kementerian Agama Republik Indonesia.

Arsyad, Azhar. 2005. LKPD Pembelajaran. PT Raja Grafindo Persada: Jakarta.

Djorghy, Prabawati (2019) Implementasi Sistem Computer Assisted Test (CAT) Dalam Rangka Penjaringan Perangkat Desa Di Kedungpeluk Kecamatan Candi Kabupaten Sidoarjo.

Karim, Muchtar A. 1997. Pendidikan Matematika I. Depdikbud: Jakarta

Lilis Nurliawaty (2017) Lembar Kerja Peserta Didik (LKPD) Berbasis Problem Solving Polya.

Russeffendy. 1992. Pendidikan Matematika 3. Jakarta: DEPDIKNAS

Senam, Arianingrum, R., Permanasari dan Suharto. 2008. Efektifitas Pembelajaran Kimia Untuk Siswa SMA Kelas XI dengan Menggunakan LKS Kimia Berbasis Life Skill. Jurnal Pendidikan Didaktika, 9 (3), 280-290. 
Sri Latifah (2016) Pengembangan Lembar Kerja Peserta Didik (LKPD) Berorientasi Nilai- Nilai Agama Islam melalui Pendekatan Inkuiri Terbimbing pada Materi Suhu dan Kalor.

Sriyono. 1992. Teknik Belajar Mengajar dalam CBSA. Jakarta:Rineka Cipta.

Sugiyono.2010. Metode Penelitian Kualitatif Kuantitatif dan R\&D. Bandung : Alfabeta

Susanto, Ahmad. 2013. Teori Belajar Pembelajaran. Jakarta: Kencanar

Sutrisno, Eko. 2014. CAT BKN Untuk Indonesia. Jakarta: BKN. 